\title{
Could We Catch a Glimpse of An Entrepreneurial Citizen? - A Qualitative Study in Upper Secondary School in Sweden.
}

\author{
Eva-Lena Lindster Norberg \\ Department of Education \\ Umeå University \\ Eva Leffler \\ Department of Education \\ Umeå University \\ Jörgen From \\ Department of Education \\ Umeå University
}

\begin{abstract}
For many years, educational curricula have been a tool for countries to foster the 'right' kind of future citizens. Since the 1980s, there has been an increasing global desire to create entrepreneurial citizens who possess certain abilities. This article will analyse what kind of citizen appears to be fostered when entrepreneurship is emphasised in school. The study is based on empirical research carried out in three geographically separated upper-secondary schools participating in an entrepreneurial program in Sweden. Interviews were performed with pupils in single-gender focus groups. Interviews with teachers were also completed with the help of cognitive maps. Furthermore, a framework was formulated for understanding the general abilities all pupils should develop according to secondary education curricula. These abilities formed four categories: factual knowledge/abilities, learning abilities, civic understanding/abilities and entrepreneurial abilities. When pupils' voices are heard, and when their stories and conceptions about their future abilities are defined, it is clear that stories about entrepreneurial abilities are predominant. However, no stories about civic understanding abilities or learning abilities are given, and this is the most interesting result of this study. Is this lack of pupils' understanding regarding the importance of civic abilities worrying and something to be concerned about when fostering future citizens through education?
\end{abstract}

Keywords: entrepreneurship in school; citizenship; abilities; secondary school,

\section{INTRODUCTION}

Schools and education have always played an important role in the development of future citizens. Educational curricula have therefore historically reflected various perspectives on how to foster the ideal citizen, with different abilities and skills desirable in particular time periods. In Sweden, the elementary school was created in 1842. At that time, the ambition was to create an obedient national citizenry through Christian education with a clear nationalist orientation (National Agency for Education, 2011b). After the World Wars, the focus in education shifted, moving towards the construction of democratic citizens with critical awareness, independence and willingness to cooperate (SOU, 1946:31). This was followed by a period in which the primary goal of education was to create equality and build a nonsegregated society (Dahlstedt and Olson, 2014; Rothstein and Westehäll, 2005). 
Globalisation and marketisation started to influence school policy more directly in the early 1990s, and organisations like the European Union and the Organisation for Economic and Cooperation and Development (OECD) came to play an active role in formulating curricula-not only in Sweden but also in Western countries (Olofsson, 2009; Sivesind, Van der Akker and Rosenmund, 2012). A noticeable example of this influence is the notion of 'lifelong learning', which originated from the international debate on economic growth and employment problems in the 1980s and was particularly significant in Swedish upper-secondary school curricula in 1994. Education was supposed to create employable citizens who were able to adjust to changes in working life, new technologies, internationalisation and a knowledgebased society. Around the same time, the ideas of fostering entrepreneurs and developing entrepreneurial abilities were introduced into policy as important pedagogical needs by OECD (1989) and the European Commission (1998). The European Commission stated that knowledge about entrepreneurship was beneficial for everyone since it would stimulate young people to become more creative and more confident in whatever they might undertake (Leffler and Mahieu, 2010).

Entrepreneurship in school as an approach to teaching and learning was introduced from two perspectives: a narrow and a broad perspective. Overall, the focus of the narrow perspective is on how to start and run businesses, whereas the broad perspective focuses on how to stimulate entrepreneurial abilities in every school subject. Thus, entrepreneurship in school became connected with a variety of teaching methods-activity-based teaching, working with problem-solving, authentic issues, working with surrounding society and teachers working as co-workers-with a primary focus on active learning (Backström-Widjeskog, 2010; Jones and Iredale, 2014; Leffler, 2009; Svedberg, 2007; Bager and Løwe Nielsen, 2009, Cope, 2005). In Swedish upper-secondary school curricula, both perspectives are included:

The school should stimulate pupils' creativity, curiosity and self-confidence as well as their desire to explore and transform new ideas into action, and find solutions to problems. Pupils should develop their ability to take initiatives and responsibility, and to work both independently and together with others. The school should contribute to pupils developing knowledge and attitudes that promotes entrepreneurship, enterprise and innovative thinking. As a result the opportunities for pupils to start and run a business will increase. Entrepreneurial skills are valuable in working and social life and for further studies. (National Agency of Education, 2011b:5-6)

There has been considerable debate on entrepreneurship in school, both as a concept and as a phenomenon (Berglund and Holmgren 2013; Johannisson, 2010; Leffler, 2009). While the concept of entrepreneurship originated in the economic and financial sectors, much of the research on entrepreneurship education is related to the field of economics rather than the field of education (e.g. Hytti et al., 2010; Jones and Iredale, 2010; Lackéus, 2013; Sarasvathy and Venkataraman, 2011; Vaidya, 2014). Critics argue that increased marketisation and the ideology of neo-liberalism may have too much impact on education, and that the emphasis on entrepreneurship may become more essential than solidarity and democracy, raising questions as to what values entrepreneurship brings to education (e.g. Carlbaum, 2012; Dahlstedt and Hertzberg, 2011, 2014; Dahlstedt and Olson, 2014). Clearly, there are different beliefs and understandings about what entrepreneurship in school includes-and where and when it is possible (Svedberg, 2010, Leffler, 2014). Even so, considerable efforts have been made to implement entrepreneurship in Swedish schools (Holmgren and Berglund, 2007; Leffler, 2006; National Agency of Education, 2010), and different educational initiatives have been adopted in Sweden to educate teachers to work with entrepreneurship in school. 
The present study is part of a three-year school improvement program on entrepreneurship in school, launched in Sweden in 2012 and funded and governed by an independent research institute, Ifous (Innovation, research and development in school). The program involves teachers and principals in secondary and upper-secondary schools from different parts of Sweden (27 schools in total). The overall aim of the program is to implement entrepreneurship in the participating schools, supported by the program.

\section{AIM AND METHOD}

Few studies provide empirical findings on pupils' experiences and voices regarding entrepreneurship in upper-secondary school in relation to their teachers' views. The aim of this article is to study what kind of citizen appears to be fostered when entrepreneurship is emphasised in school. We will discuss this through three perspectives: curricula, pupils' voices and teachers' voices. The article is organised as follows. We will start with the theoretical framework and then present the results in three steps: first there will be a description of what kinds of abilities must be brought forth as the overall task of upper-secondary schools; second, there will be an analysis of what kinds of abilities the pupils emphasise as important for their future lives; third, as the pupils almost entirely emphasise entrepreneurial abilities, there will be an analysis of teachers' views on entrepreneurial abilities. Finally, we will discuss entrepreneurship in school and its relation to the school's fostering mission.

The empirical material consists of curricula for upper-secondary schools, research materials, policy reports and interviews with pupils and teachers. The sampling of schools was done in two stages. The first stage was based on a questionnaire by which participating schools, which extensively indicated that they were working with entrepreneurship in school, were identified. In stage two, three of those schools, geographically separated in Sweden, were selected. A total of 90 pupils, ranging from 16-19 years old and derived from both vocational programs and programs preparing for higher education, were interviewed for about one hour in focus groups divided by gender ( 26 total groups). This design was chosen to allow for dynamic interactions in which the pupils' voices could come together to offer their perspectives about the abilities they believed to be important to their future lives (cf. Morgan and Kreuger, 1993; Tursunovic, 2002; Wibeck, 2010). In addition, 14 teachers (10 male and 4 female) were interviewed regarding entrepreneurial abilities in education, using cognitive maps (Scherp, 2002, 2013). According to Scherp (2013), a cognitive map can be seen as a graphical representation and an overview of an individual's mental landscape and his or her conception of a phenomenon, in this case, a teacher's conception about the phenomenon of entrepreneurship in school. The transcribed interviews were systematically organised with the help of NVivo, a data analysis software application designed for qualitative research.

In research as well as in practice, different concepts are used when discussing and defining entrepreneurship in a school context. In this article, three main concepts are used: entrepreneurial abilities, which refer to the entrepreneurial abilities used in the Swedish curricula; entrepreneurship in school, which aims to stimulate entrepreneurial abilities, both from broad and narrow perspectives; and entrepreneurial citizens, referring to someone who has developed and possesses the entrepreneurial abilities determined to be necessary in tomorrow's society. 


\section{Entrepreneurial citizens}

\section{FRAMEWORK}

Studying how young people develop themselves as citizens is a complex task, but education and its relationship to the development of future citizens is an established area of educational research (e.g. Lister et al., 2007; Olson et al. 2014; Keating, 2014). However, few studies have aimed at problematising entrepreneurship in school and citizenship from different perspectives (e.g. Dahlstedt and Hertzberg, 2012; Deuchar, 2004, 2006; Holmgren and From, 2005; Korhonen et al., 2012).

Marshall (1950) established the long agreed upon definition of citizenship. This definition consists of three types of citizenship, which guarantee individuals a number of rights but also feature obligations: civil, political and social citizenship. Education is considered to be a part of social citizenship and entails rights for the people while guaranteeing that the nation is able to maintain the welfare state. Today's research takes a broader and more complex approach to citizenship, including issues about identity, social position, cultural beliefs and affiliation (Fejes, 2012; Keating, 2014). Since the late 1980s, there has also been discussion regarding active and passive citizenship (Hartsman and Persson, 2013; Irisdotter Aldenmyr et al., 2013). Active citizenship is defined by the European Commission in the following way:

Learning for active citizenship includes access to the skills and competences that young people will need for effective economic participation under conditions of technological modernization, economic globalization, and, very concretely, transnational European labour markets. At the same time, the social and communicative competences that are both part of new demands and which flow from changing work and study contexts are themselves of critical importance for living in culturally, ethnically and linguistically plural worlds. These competences are not simply desirable for some, they are becoming essential for all. (European Commission, 1998:12)

The active citizen is described as someone who can actively participate in the labour market in a changing world and is also social and communicative to cope with social life. This definition of active citizenship is consistent with what Carlbaum (2012), Dahlstedt and Hertzberg (2011) and Dahlstedt and Olson (2014) argue emerges as the dominant civic discourse in the governing documents of Swedish upper-secondary schools. The definition of a citizen that Marshall presented in the 1950s seems to no longer be accurate; rather, a different view has emerged of a citizen who can no longer expect anything but is instead expected to be active, responsible and have the ability to quickly adapt to current circumstances (Carlsson, 2006; Nordin, 2012; Scourfield, 2005). Citizenship has become something that is constructed and created rather than something that people have and are (Chriushank, 1999). The fostering of children and young people in school is framed by the current dominant discourse regarding the qualities of an imaginary desirable future citizen. Education reforms, therefore, design and frame what is considered to constitute desirable citizenship in the future (Carlbaum, 2012).

However, in the dominant discourse as well as in policy, entrepreneurial abilities appear to be crucial for becoming an active citizen, and the desire to foster entrepreneurial citizens does not appear to be decreasing; in fact, it appears to be reinforced. The European Commission (2012) argues that the development of a citizen possessing entrepreneurial abilities is essential for domestic growth and vital for sustainable local and regional development as well as social cohesion. It can thus be argued that entrepreneurship and entrepreneurial abilities are important concepts for defining what is considered essential to citizenship in our time-and in 
future society-by the Swedish curricula. In many ways, it seems like the idea of an active citizen coincides with an individual that possesses entrepreneurial abilities.

\begin{abstract}
Abilities
In recent years, empirical research has emerged regarding the abilities important for success later in life (e.g. Chuna and Heckman, 2010; Vestman and Lindqvist, 2012). According to Brunelli and Schlotter (2011), the entrepreneurial abilities presented in the EU key competences could be considered non-cognitive. Non-cognitive abilities refer to attitudes, behaviour and social emotions and include self-confidence, motivation, self-discipline and good manners, whereas cognitive abilities are linked to mental activity and can be measured via intelligence and knowledge tests (National Agency for Education, 2013). In practise, it can be difficult to distinguish between non-cognitive and cognitive abilities. Assessments in schools have traditionally been focused on cognitive abilities since they are easier to measure. Nylén and Skarin (2009) argue that extensive national and international measurement entails the risk that teaching will be based on what is to be evaluated. According to Lackéus and Moberg (2013), entrepreneurship in school is on a collision course with the prevailing social trend towards more centrally controlled schemes with several national examinations.
\end{abstract}

\title{
FINDINGS
}

The present study was conducted in three stages. The point of departure was an analysis of one part of the upper-secondary school curriculum, called Tasks of the School, in order to condense and crystallise which abilities are highlighted as the most important for a pupil to have acquired by the time his or her education is completed. The next step was to identify pupils' conceptions about their future abilities by conducting interviews and comparing the results with the abilities included in the curriculum. The last step was to review teachers' views of entrepreneurial abilities since the pupils were emphasising those abilities in the study.

\section{Tasks of the school}

School curricula represent society's demands for what education and training should contain and develop and also reflect what type of future citizen is desired. In the Swedish uppersecondary school curriculum, it is specified that education should transfer values, impart knowledge and prepare pupils to participate and work actively in the community. Necessary abilities for pupils to acquire are described in the curriculum under the heading Tasks of the school. The model shown in Table 1 illustrates how these abilities are analysed and categorised into four themes: Factual knowledge abilities, Learning abilities, Civic understanding/abilities and Entrepreneurial abilities. Factual knowledge abilities can be viewed as cognitive abilities, whereas the others are considered non-cognitive. These abilities are explicitly formulated in the curriculum. The first category is about equipping pupils with factual knowledge, which should provide them with a common framework of knowledge and references that mirrors the current society.

The second and third categories are about equipping pupils with certain artefacts so they can become active citizens in a changing society. Both categories are stated as fostering tasks. The fourth category is about developing entrepreneurial abilities so that pupils are prepared to be entrepreneurs in society, whether in the labour market or in further studies, and this category is also regarded as a fostering task. In the curriculum, no category of abilities is described as superior to any other category; all four categories are defined as equally important. 
Table 1 Tasks of the school

\begin{tabular}{|c|c|c|c|}
\hline $\begin{array}{l}\text { Factual knowledge } \\
\text { abilities }\end{array}$ & $\begin{array}{l}\text { Learning } \\
\text { abilities }\end{array}$ & $\begin{array}{l}\text { Civic } \\
\text { understanding/ } \\
\text { abilities }\end{array}$ & Entrepreneurial abilities \\
\hline $\begin{array}{l}\text { All Subjects } \\
\text { Health } \\
\text { Lifestyle } \\
\text { Consumer issues } \\
\text { European Union }\end{array}$ & $\begin{array}{l}\text { Lifelong learning } \\
\text { Able to assimilate } \\
\text { knowledge } \\
\text { Critical thinking } \\
\text { Dynamic thinking } \\
\text { Personal standpoint }\end{array}$ & $\begin{array}{l}\text { Democratic values } \\
\text { Human Rights } \\
\text { International solidarity } \\
\text { Multiculturalism } \\
\text { Future understanding } \\
\text { Environmental } \\
\text { awareness }\end{array}$ & $\begin{array}{l}\text { Creativity } \\
\text { Curiosity } \\
\text { Self-Confidence } \\
\text { Transform new ideas into action } \\
\text { Solve problems } \\
\text { Take initiative } \\
\text { Responsibility } \\
\text { Work independently } \\
\text { Work with others } \\
\text { Social competences } \\
\text { Communicative competences }\end{array}$ \\
\hline Cognitive abilities & $\begin{array}{l}\text { Non-Cognitive } \\
\text { abilities }\end{array}$ & Non-Cognitive abilities & Non-Cognitive abilities \\
\hline Goal & Goal & Goal & Goal \\
\hline $\begin{array}{l}\text { Give the pupils a } \\
\text { common frame of } \\
\text { reference }\end{array}$ & $\begin{array}{l}\text { The ability to live in } \\
\text { a changing society }\end{array}$ & $\begin{array}{l}\text { Create an engaged and } \\
\text { active citizen }\end{array}$ & $\begin{array}{l}\text { Create an entrepreneurial citizen, who is able to } \\
\text { start a business, think innovatively and promote } \\
\text { entrepreneurship } \\
\text { The entrepreneurial abilities should also prepare } \\
\text { pupils for labour market and further studies }\end{array}$ \\
\hline Tasks & Tasks & Tasks & Tasks \\
\hline Knowledge tasks & Fostering tasks & Fostering tasks & Fostering tasks \\
\hline
\end{tabular}

\section{Pupils' voices}

The following section presents pupils' views on which abilities they believe will be necessary in the future. The same categories as above, derived from the curriculum, were used as a framework for categorising the abilities pupils mentioned during the interviews. The numbers in parentheses show the number of groups who expressed the importance of the specific ability.

Table 2 Pupils' voices about needed abilities

\begin{tabular}{|l|l|l|l|}
\hline Factual knowledge & Learning abilities & $\begin{array}{l}\text { Civic } \\
\text { understanding/ } \\
\text { abilities }\end{array}$ & $\begin{array}{l}\text { Entrepreneurial } \\
\text { abilities }\end{array}$ \\
\hline English (4) & & $\begin{array}{l}\text { Social competence (12) } \\
\text { Working with others (9) } \\
\text { Responsibility (7) } \\
\text { Electrical knowledge (3) }\end{array}$ \\
Computer science (2) & & & Working independently \\
Swedish (2) & & (6) \\
Language (2) & & Communicative \\
Religion (1) & & Self-confidence (3) \\
Economics (1) & & Taking initiative (3) \\
Psychology (1) & & \\
Physics (1) & & \\
Rhetoric (1) & & & \\
Leadership (1) & & & \\
\hline
\end{tabular}

Placing pupils' voices and their conceptions of future abilities into the four categories allows the pupils' statements to be clarified. As can been seen in Table 2, not a single pupil mentioned abilities that could be placed in the categories of civic understanding/abilities or learning abilities. On the other hand, entrepreneurial abilities were frequently expressed. However, as mentioned above, all four categories have the same importance and weight within the curriculum were Task of the school is presented. The pupils ranked some entrepreneurial abilities as having higher value than others, for instance, social competences, working with others and responsibility. Abilities such as curiosity, creativity, problem-solving and 
transforming new ideas into action were not brought up at all. Other abilities not described in the curriculum-but closely connected to entrepreneurial abilities-were also mentioned, such as being proactive, being motivated and learning by doing. Additional abilities were also highlighted. Some of them related to practical matters like being able to pay bills, clean a house and being experienced:

You should not be afraid to make new contacts. I do not think it's so important that you are good at spelling. (Girl, 17 years)

It is notable that factual knowledge is not a priority for young pupils when they consider the abilities they will need in the future. Understanding how to network, learning responsibility and daring to take initiative are more important than knowing how to spell or understanding integrals:

The most important thing you learn in school that really matters is responsibility and stuff. To solve the double integrals is perhaps not the most important. (Boy, 17 years)

This is also visible in Table 2, where only a few groups believed that acquisition of knowledge in different subjects is important. Have non-cognitive abilities become more important as the curriculum presents them as essential for getting a job and coping with a changing society? This is in line with the previous ideas of Heckman et al. (2006), who state that non-cognitive abilities are important for pupils' chances to be attractive to the labour market:

\section{Take initiative and therefore dare, dare to fail in order to succeed. (Girl, 18 years)}

The intense contemporary public debate on issues regarding international tests and international ranking (i.e. PISA) seems to have had little impact on the pupils, and Swedish students' test results have dramatically decreased during recent years. While pupils are talking about the need for entrepreneurial abilities, in the public debate regarding schools, the discussion is often centred on international knowledge measurements and the general position that pupils' knowledge of different subjects must increase. This highlights an interesting underlying contradiction between the view of the individual (what I benefit from in my future life) and the dominant discourse (what the future society benefits from). What discourse is dominant in the classroom? Which values and abilities are mediated and emphasised?

This underlying contradiction reveals the complexity of the fostering tasks for the entire school system, which in turn relates to the multiplex mission teachers have in schools and the inadequacy of strategic thinking regarding how the development of democratic abilities and values should permeate the whole of education (Broman, 2009; Englund, 2003). As a consequence, it appears that these abilities are not really visible or understandable for the pupils. At the same time, pupils and young people are often described as more individualistic, and therefore they do not see civic abilities as important (e.g. Beach and Dovemark, 2011; Dalton, 2006). Pupils do not view learning abilities as important either, and according to Boström (2011) and Jørgensen (2010), there is too little time devoted in schools to deepening those abilities.

When summarising pupils' conceptions about future abilities, it is obvious that they are closely connected to entrepreneurial abilities, and learning abilities and civic understanding/abilities are not mentioned at all. One explanation for the dominance of entrepreneurial abilities among 
the pupils could be that the schools are participating in a school improvement program focused on entrepreneurship in school; thus, entrepreneurial abilities may have been emphasised in their education and presumably considered to be valuable. This school improvement program is conducted in an educational context, where the presumed benefit of developing young people's entrepreneurial abilities has been a dominating discourse for some time (Deuchar, 2006; Johansen, 2012; Jones and Iredale, 2010; Moberg, 2014; Otterborg, 2011). The presumed advantages of integrating entrepreneurship in school curricula have been discussed since the 1980s, and they have had an impact on education and debates regarding school improvement (Mahieu, 2006), which in turn may have affected teachers' and pupils' views of what is important to learn in school. In order to gain a deeper understanding of the complexity of the process of fostering future citizens, it therefore becomes relevant to analyse the teacher's views on entrepreneurial abilities.

\section{Teachers' views on entrepreneurial abilities}

As described above, teachers were asked to explain and discuss their views on entrepreneurial abilities and to present them in a cognitive map. In Table 3 below, the answers from the cognitive maps are condensed. The number in parentheses indicates the number of teachers who mentioned each of the abilities listed.

Table 3. Teachers' views on entrepreneurial abilities

\begin{tabular}{|l|l|}
\hline Entrepreneurial abilities & \\
\hline Creativity (6) & Working with others (3) \\
\hline Responsibility (6) & Communicative competences (1) \\
\hline Taking initiative (5) & Working independently (1) \\
\hline Self-confidence (4) & Social competences (1) \\
\hline Curiosity (3) & Solving problems (1) \\
\hline Transforming new ideas into action (3) & \\
\hline
\end{tabular}

Table 3 illustrates that when teachers defined entrepreneurial abilities, they primarily talked about creativity, responsibility and taking initiative. They also mentioned other abilities not stated in the curriculum that they understood to be related to entrepreneurial abilities for instance, lust and needs, enthusiasm, motivations and the ability to become a proactive person. Some other abilities the teachers highlighted were learning abilities, such as boundless learning, interest in learning and hunger for knowledge. In teachers' statements about what characterised pupils who possess entrepreneurial abilities, learning and interest in learning appeared to be significant:

\section{He has a hunger, he wants to learn, he really wants to learn. (Male teacher)}

One would hope that all pupils would be interested to learn. It is clear that they are not interested in all subjects, but that an entrepreneurial pupil has a genuine motive to learn new things. I think that it is this kind of pupil. (Female teacher)

Active I think, interested I think, do not know if it's silly, but I think that if you work entrepreneurially, there is a greater chance that you become interested as a pupil and also active as well. That's what I think is the meaning of entrepreneurship in school, the pupil should be active and, not just sit and receive knowledge. (Female teacher)

Pupils possessing entrepreneurial abilities are thus pictured as pupils who have a great interest in school and are engaged, active and creative. However, these are not abilities that the pupils mentioned as important. In fact, pupils emphasised different entrepreneurial abilities 
than the teachers, and they defined different abilities as entrepreneurial. For instance, pupils emphasised social competence, working together with others and working independently, whereas teachers highlighted creativity-an ability the pupils did not mention at all.

It is obvious that even though the pupils emphasised entrepreneurial abilities as important for their future, they did not agree with teachers as to which entrepreneurial abilities are important. However, there was a single ability that both teachers and pupils highlighted: responsibility. This is one of the most common abilities teachers mentioned when discussing which entrepreneurial abilities they thought were most important for pupils:

But I still think they will land in responsibility and some may not have a clue. I think, but I do not know how the allocation is but I have a feeling of that the majority will talk about responsibility. (Female teacher)

They will talk a lot about responsibility. I believe that they will talk about things that can be put under the concept responsibility. (Female teacher)

The concept of responsibility has become more evident in recent curricula in Swedish schools, but it can be tracked much further back in the educational discourse, with different content and different meanings. Since the 1960s and 1970s, the concept has changed from a sense of cooperative responsibility to an individual responsibility associated with flexibility, individualism and a desire to have an autonomous and responsible pupil who works toward established goals (Arnot, 2004; Sjöberg, 2006). According to Dahlstedt (2007), an active, selfconscious and responsible person represents an ideal citizen. Responsibility is an important issue when entrepreneurship is carried out in school because it is largely based upon the motivation of the pupils.

Thus, similar to the contradiction between the curricula and pupils' views, there is a contradiction between the pupils' views and those of their teachers. Research reported by Carlbaum (2012), Dahlstedt and Hertzberg (2011) and Dahlstedt and Olson (2014) indicates that there are two dominant discourses regarding citizenship in the Swedish upper-secondary school curriculum. One focuses on the entrepreneurial citizen, described as a citizen ready to actively take part in society, and the other is a more social and communicative citizen, ready to manage social life. Those discourses may be understood and interpreted differently by teachers and the pupils, where the teachers are trying to adjust to the entrepreneurial discourse and the pupils to the idea of social and communicative citizenship. This is in line with Ball (2010), who states that the mechanisms of an 'advanced' liberal society alter the very meaning of being a teacher, creating new teacher subjects that talk about and emphasise neoliberal values-which are often referred to in education as connected to developing entrepreneurial abilities (Carlbaum, 2012; Dahlstedt and Olson, 2014; Komulainen et al., 2011).

\section{CONCLUDING DISCUSSION}

The aim of this article was to study what kind of citizen appears to be fostered when entrepreneurship is emphasised in school. To fulfil this aim, we analysed a part of the curriculum and interviews with both pupils and teachers. The result from the analyses of the curriculum indicated four main categories of abilities that pupils are supposed to develop during upper-secondary school. Three of those categories are considered fostering tasks: Learning abilities, Civic understanding/abilities and Entrepreneurial abilities. The goal of each 
of these is to create citizens prepared for active and flexible lives after leaving school. The fourth category is a knowledge task, that is, giving pupils solid factual awareness about a range of different subjects. All the abilities described should transfer values, impart knowledge and prepare pupils to act and work in the community.

Fostering pupils' civic development in school is a multifaceted issue, but by taking an educational position the school is also, by extension, defining the meaning of a good citizen and what kind of society such a citizen is expected to join. This study highlights the complexity of the process of fostering future citizens, particularly in terms of the contradictions between the views of the curricula, the pupils and the teachers. Entrepreneurship in school appears to affect the way in which pupils relate to entrepreneurial abilities. It is possible to catch a glimpse of entrepreneurial citizenship in the pupils' conceptions regarding the abilities that they believe will be important to their futures. One interpretation for this is that the pupils have adapted to the prevailing entrepreneurial citizen discourse, and that they recognise some additional abilities as useful. It is essential to remember that a school can never be regarded as culturally self-contained, and pupils are always shaped and formed as citizens outside the school through friends, family, media, social media, regional, national and international discourses and so on.

Teachers in the study were asked to give their views about entrepreneurial abilities since those were dominant in the pupils' answers about necessary future abilities. However, the teachers emphasised other abilities than the pupils did. While the teachers expressed that their mindsets were changing and that they used rhetoric connected to entrepreneurial abilities more frequently, there remains a gap between teachers and pupils. Teaching is all about the development of pupils' mind-sets and vocabularies, and an important objective for the school is to include students in different discursive communities-that is, to equip them with different concepts and ways of thinking (Dysthe, 2001). As the study shows, pupils consider some entrepreneurial abilities within the entrepreneurial discourse important for handling the future. Interestingly, the teachers were, to a large extent, emphasising creativity, whereas the pupils did not talk about it at all. The pupils did not talk about solidarity and social engagement either, and this leads to a question: What kind of entrepreneurial citizen is being shaped? Does a more social and communicative citizen emerge as the students talk to a great extent about social competences?

As Fernandez (2012) indicates, the fostering tasks for schools are composed both implicitly and explicitly, concerning different values and particular cultural characteristics, implying that some citizens/pupils are not fully included. In conclusion, there are concerns about highlighting entrepreneurial abilities. There are also class and gender perspectives (e.g. Beach and Dovemark, 2011; Carlbaum, 2012; Korhonen, Komulainen and Räty, 2011; Leffler, 2012; Sjöberg, 2011) as well as a concern that democratic values must stand back in education, as the results indicate in this case. The European Union has stressed the importance of citizens becoming more entrepreneurial in all walks of life. In many ways, it seems as if the concept of the active citizen coincides with the definition of the entrepreneurial citizen. Hence, the question is whether the desire to foster entrepreneurial citizens undermines other highly valued abilities connected to civic understanding/abilities, learning abilities and factual knowledge. Is there, as Irisdotter et al. (2013) discuss, a neo-liberal colouring of the concept of citizenship, moving away from democratic and solidarity values, gradually taking place in education? The challenge perhaps lies in achieving an educational balance that enables the fostering of cosmopolitan identity (Hargraves, 2003). It appears that schools and teachers must deepen their knowledge of how to use entrepreneurial abilities to widen and integrate both learning abilities and civic abilities in a common fostering task. The most important result 
of this study indicates that we should reflect on what we value and what we emphasise in education. The lack of pupils' acknowledgment of and concern for civic abilities is worrying.

This study has also raised several questions requiring further investigation. For example, are pupils actually becoming entrepreneurial citizens or is this just rhetoric? What entrepreneurial abilities must teachers really talk about with their pupils in the course of their daily teaching practices? Does every pupil have access to entrepreneurship in school that will allow him or her the opportunity to 'qualify' in society and become an entrepreneurial citizen?

The relationship between enterprise and citizenship education is a close one, and it is possible that one may lend itself to the other. But the potential of enterprise education as a means of promoting the new expectations of the citizenship agenda will perhaps depend very much on how schools conceptualise their meaning of enterprise' to begin with. (Deuchar, 2004:238)

\section{ACKNOWLEDGEMENTS}

The authors gratefully acknowledge financial support from Ifous and Umeå University, Sweden, which made it possible to follow the school improvement program and to obtain access to the research field.

\section{References}

Arnot, M. (2004). Educating-Learner-citizens for social change to citizenship education in contemporary/sociaty. Paper presented at the NEPF/NERA Conference. Reykjavik, Island.March 11-13

Backström-Widjeskog, B. (2010). Teachers thoughts on entrpreneurship education In Creativity and Innovations Preconditions for entrepreneurial education, edited by Kjell Skogen and Jarle Sjøvoll, 107-120.Trondheim: tapir academic press.

Bager, T., \& Nielsen, S. L. (2009). Entreprenurship and competences. Copenhagen: Borsen.

Beach, D., \& Dovemark, M. (2011). Twelve years of upper-secondary education in Sweden: the beginning of a neoliberal policy hegemony. Educational Review 63 (3): 313-327. doi: 10.1080/00131911.2011.560249.

Berglund, K. (2007). Jakten på entreprenörer-om öppningar och låsningar i entreprenörskapsdiskursen [The hunt for entrepreneurs- on opening and closings in the entrepreneurship discourse]. Västerås: Arkitektkopia.

Berglund, K. (2013). Fighting againstt all odds : Entreprenuenurial education as employability training. ephemera theory \& politics on organisation 13 (4): 717-735.

Boström, L. (2011). Students learningsstyles compared with their teachers learning styles in upper secondary school-a mismatched combination. Education Inquiry 2 (3): 475-495

Broman, A. (2009). Att göra en demokrat. [ To do a democrat ]. Phd dissertation., University of Karlstad: Universitetstryckeriet in Karlstad.

Brunelli, G., \& Schlotter, M. (2011). Non-Cognitive Skills and Personality Traits: Labour Market Relevence and their Development in Education \& Training Sysytem. Bonn: Study of Labour.

Carlbaum, S. (2012). Blir du anställningsbar lille/a vän- diskursiva konstruktioner av framtida medborgare i gymnasiereformerna 1971-2011 [Are you employable dearie-discursive constructions of future citizens in upper secondary school ].PhD dissertation., University of Umeå: Print and Media.

Chuna, F., \& Heckman, J. J. (2010). Investing in our young people. Cambridge: National burea of Economic Research.

Cope, J. (2005). Towards a Dynamic Learning Perspective on Entrepreneurship. Entreprenurship Theory \& Practice Journal, 29 (4): 373-397. doi 10.1111/j.1540-6520.2005.00090.

Dahlstedt, M. (2007). I val(0)frihetens spår, segregation, differentiering och två decennier av skolreformer [ The consequences of (un) free choice policies: Segregation, defferential values and educational reform in Sweden]. Pedagogisk Forskning I Sverige, 12 (1): 20-38. 
Norberg, E. L., Leffler, E., \& From, J. (2015). Could we Catch a Glimpse of an Entrepreneurial Citizen? - A Qualitative Study in Upper Secondary School in Sweden. Advances in Social Sciences Research Journal, 2(11) 11-24.

Dahlstedt, M., \& Hertzberg, F. (2011). Den entreprenörskapande skolan styrning och subjektskapande och entreprenörskapspedagogik [Schooling Entrepreneurs; Entrepreneurship, Govermentality, and Education]. Pedagogisk Forskning I Sverige, 3(16): 179-198.

Dahlstedt, M., \& Olson, M. (2014). Medborgarskapande för ett nytt millenium- Utbildning och medborgarfostran i 2000 -talets Sverige [Citizenship in the making of a new millenium-education and citizen formation in 21st century in Sweden]. Demokrati \& Utbildning, 23(2):7-25.

Dalton, R.(2006) Politics:public opinion and political parties in advanced democracies Washington DC: CQ Press

Deuchar, R. (2004). Changing paradigms, the Potential of Entreprise Education as an Adequate vehicle for Promoting and Enhancing Education for Active and Responsible Citizenship: from a Schottish perspective. Oxford Review of education, 30(2):223-239. doi: 10.1080/0305498042000215539.

Deuchar, R. (2006). Not only this but also that. Translating the social and political motivations underpinning enterprise and citizenship education in to Scottish schools. Cambridge journal of education, 36 (4):533-547. doi:10.1080/03057640601049157

Dysthe, O. (2001). Dialog, Samspel och Lärande.[Dialogue, Interaction and Learning] Lund: Studentlitteratur.

Englund, T.(2003) Skolan och demokratin -på väg mot en skola för deliberativa samtal [School and the democracy-School and democracy-towards a school for deliberative conversations] In Demokrati och lärande om valfrihet, gemenskap i skola och samhälle[Democracy and learning about choce, community in school and sociaty] edited by Britta Jonsson and Klas Roth, Lund: Studentlitteratur.

European Commission. (1998). Fostering Entreprenurship in European priorities for the future. Bryssel: Europeiska Kommissionen.

European Commission. (2004). Action Plan: Agenda For Entreprenurship. Brussels: Commission of the European Communities.

European Commission. (2012). Entrepreneurship education at school in Europe- National strategies curricula an learning outcomes. Bryssel: Eurydice.

European Commission. (2014). Expert Group on Indicators on Entreprenurial Learning and Competences: Final Report.Bryssel: European Commission.

Falk-Lundqvist, Å., Hallberg, P.-G., Leffler, E., \& Svedberg, G. (2011). Entreprenöriell pedagogik i skolan drivkrafter för elevers lärande [Entrepreneurial education in school driving force for students learning] Stockholm:Liber

Fernandez, C. (2012). Liberaliseringen av svensk skolpolitik. En positionsbestämning. [Liberalisation of Swedish school policy. A position] Statsvetenskaplig tidskrift, 114 (2):241-270

Hargreaves, A. (2005). Extending Educational Change. Dordrecht, Netherlands: Springer.

Heckman, J. J., Stixrud, J., \& Urzua, S. (2006). The Effects of Cognitive and Noncognitive Abilities on Labor Market Outcomes and Social Behaviour. Journal of labour economics, 24 (3): 411-482.

Hytti, U., Stenholm, P., Heinonen, J., \& Seikkula-Leino, J. (2010).Percevied learning outcomes in entrepreneurship education. Education + Training, 54(8/9): 587-606.

Hörnqvist, M.-L., \& Leffler , E. (2014). Fostering an entreprenurial attitude: challenges in the leadership of school principales. Education + Training, 56 (6): 551-561.

Irisdotter Aldenmyr, S., Jeppson Wigg, U., \& Olson, M. (2013). Education, Citizenship and Social Justice. Journal of Education \& Work, 26(4): 453-571.

Johanisson, B. (2010). The agony of the Swedish school when confronted by entreprenurship. In Creativity and Innovasion, edited by Kjell Skogen and Jarle Sjovoll, 91-104. Trondheim: tapir academic press.

Johansen, J.-B. (2012). Skapende og Kreativ laering- Pedagogisk entreprenørskap i forskning og utvikling av laeringsprosesser. Trondheim: tapir academic press.

Jones, B., \& Iredale, N. (2010). Enterprise education as pedagogy. Education and training, 52 (1): 7-19. DOI 10.1108/00400911011017654

Jørgensen, C.H. (2010) Frafald i den danska ungdomsutdannelserna In Frafall for 16-20 åringar i Norden edited by Eifrid Markussen. Copenhagen: Nordiska Ministerrådet 
Komulainen, K., Naskali, P., Korhonen, M., \& Foley, S. (2011). Internal Entrepreneurship- A Trojan Hourse of the Neoliberal Governance of education? Finnish-Pre and Service Teachers Implementation of and Resistance toward Entrepreneurship education. Journal of critical education policy studies, 9 (1): 341-371.

Lackéus, M. (2013). Entreprenöriellt lärande, vad innebär det och vilken betydelse kan det ha-en kunskapsöversikt [Entrepreneurial learning, what does it mean and what impact can it have-a knowledge overview]. Kommunförbundet Skåne.

Lackéus, M., \& Moberg, K. (2013). Entreprenörskapsutbildning från ABC till Phd [Entrepreneurship Education from ABC to PHD]. Stockholm: Entreprenörskapsforum.

Leffler, E. (2009). The many faces of Entrepreneurship: a discursive battle for the school arena. European Educational Research Journal 8 (1): 104-116. doi:http://dx.doi.org/10.2304/eerj.2009.8.1.104

Leffler, E., \& Mahieu, R. (2010). Entreprenörskap ett nytt fostransprojekt i skolan.[Entrepreneurship a new fostering project in education] In: Fostran i skola och utbildning: historiska perspektiv. [ Fostering in school and education] : historical perspective edited by Anna Larsson. 177-196. Uppsala: Föreningen för svensk undervisningshistoria.

Leffler, E (2012). Entrepreneurship in school and the invisible of Gender: A Swedish Context in EntrepreneurshipGender Geographies and Social Context edited by Thierry Burger Helmchen. 31-52 : In -Tech

Lingard, B., \& Ozga, J. (2007). The RoutledgeFalmer reader in education policy and politics. Oxon: Routledge Tayler and Francis group.

Lundahl, L. (2011). Paving the way to the future? Education and Young Europeans Paths to work and Independence. European Educational Research Journal, 10 (2):168-178. doi: http://dx.doi.org/10.2304/eerj.2011.10.2.168

Mahieu, R. (2006). Agent of change and policies of scale. Umeå: Print och Media.

Moberg, K. (2012). Impact of entrepreneurial education i Denmark 2012. Odense, Denmark: The Danish foundation for entrepreneurship-Young entreprise.

Moberg, K. (2014). Two approaches to entrepreneurship education: The different effects of education for and through entrepreneurship. The international journal of Management Education, 1-17. http://dx.doi.org/10.1016/j.ijme.2014.05.002

Morgan, D., \& Kreuger, R. (1993).When to use focus groups and why. In Successful Focus Groups Advancing the State of the Art edited by David.L. Morgan, 3-20. Newbury: Sage Publication.

National Agency of Education. (2011a). Läroplan, examensmål och gymnasiegemensamma ämnen för gymnasieskola 2011. [Curriculum for secondary school] Stockholm: Skolverket.

National Agency of Education. (2011b). Skolan och medborgaskapandet. [ The school and citizen making] Stockholm: Skolverket.

National Agency of Education. (2013). Forskning om skolreformer och deras genomslag[ Research on school reforms and their impact ]. Stockholm: Skolverkets Aktuella Analyser.

Nylén, J., \& Skarin, T. (2009). Framtidens utbildning i Norden-Konkurrens och samverkan i en globaliserad värld [Future education in the Nordic-Competition and cooperation in a globalized world]. Köpenhamn: Nordiska rådet.

OECD/CERI. (1989). Towards an "enterprising" culture-a challenge for education and training. Paris: OECD.

Olofsson, A. (2009). Entreprenörskapsutbildning i skolan: Formering av ny pedagogisk identitet [

Entrepreneurship Education in school: Formation of a new pedagogical identity]. Härnösand: Mid Sweden University Department of Education.

Otterborg, A. (2011). Entreprenöriellt lärande-Gymnasielevers skilda sätt att uppfatta -entreprenöriellt lärande [ Entrepreneurial learning Upper secondary school student's different perceptions of entrepreneurial learning]. PhD dissertation., School of communication and Education in Jönköping.

Pepin, M. (2012). Enterprise Education: a Deweyan perspective. Education+Training, 54(8/9): 801-812.

Rothstein, B., \& Westehäll, L. V. (2005). Bortom den starka statens politik.[ Beyond the strong government policy]. Stockholm: SNS.

Sarasvathy, S., \& Venkataraman, S. (2011). Entreprenurship as method questions for an entrepreneurial future. Theory and Practice, 35 (1): 113-123. 
Norberg, E. L., Leffler, E., \& From, J. (2015). Could we Catch a Glimpse of an Entrepreneurial Citizen? - A Qualitative Study in Upper Secondary School in Sweden. Advances in Social Sciences Research Journal, 2(11) 11-24.

Scherp, H.-Å. (2002). Lärares Lärmiljö- Att leda skolan som en lärande organisation [Teachers' Learning Environment To lead the school as a learning organization]. Karlstad: Karlstad University Studies.

Scherp, H-Å. (2013). Quantifying Qualitative Data Using Cognitive Maps. International Journal of Research \& Method in Education, 36(1): 67-81

Sivesind, K., Van der Akker, J., \& Rosenmund, M. (2012). The European Curriculum; restructing an renewal. European Educational Research Journal 11 (3): 320-327. http://dx.doi.org/10.2304/eerj.2012.11.3.320

Sjöberg, L (2011). Bäst i klassen? - Lärare och elever i svenska och europeiska policydokument [Best in class?Teachers and students in swedish and European policy's] PhD dissertation, University of Gothenburg

Sjöberg, Å. (2006). Att göra sina uppgifter vara tyst och lämna in i tid- Om elevansvar i det högmoderna samhället. [To make their tasks, be quiet and submit on time- About student responsibility in the highly modern society ] Phd dissertation, Univeristy of Karlstad.

Sjøvoll, J., \& Johansen, J.-B. (2013). Innovasjon i utdanning.[ Innovation in education] Trondheim: Akademika forlag.

SOU:1946:31. (1946). Skolans inre arbete-synpunkter på fostran och undervisning, 1940 år skolutredning betänkande och utredningar del VI. [The school's internal work-views on education and fostering, $1940 \mathrm{years}$ of school study report and investigations part VI ]Stockholm: SOU.

Svedberg, G. (2007). Entreprenörskapets avtryck i klassrummets praxis-Om villkor och lärande i gymnasieskolans entreprenörskapsprojekt. [The imprints of entreprenurship in the classrom]. Phd dissertation, University of Umeå.

Svedberg, G. (2010). Pedagogical entrepreneurship in the formulation and realisation arena In Crativity and Innovation, edited by Kjell Skogen and Jarle Sjøvoll,121-128). Trondheim: tapir academic press.

Tursunovic, M. (2002). Fokusgrupper i teori och praktik. [ Focus groups in theory and practice] Sociologisk forskning :62-89.

Vaidya, S. (2014). Developing entrepreneurial skills- Creating and Strengthening Entreprenurial Culture in Indian Schools. New Delhi: Springer.

Wennberg, K. (2011). Övning ger färdighet en långtidsuppföljning av UF-företagares entreprenöriella karriär i Sverige 1990-2007 [ A longituinal investigation of Junior Achievement Sweden Alumni and their entrepreneurial careers 1990-2007. Junior Achievment. Kungsbacka.

Vestman, R., \& Lindqvist, E. (2012). The Labour market returns to cognitive or noncognitive ability-Evidence from the Swedish Enlistment. American Economic Journal, 3(1):101-128.

Wibeck, V. (2010). Fokusgrupper-Om fokuserade grupperintervjuer som undersökningsmetod.[Focus groupsabout focused group interviews as research method] Lund: Studentlitteratur. 